\title{
Approaching the serpentine factor at a local scale - a study in an ultramafic area in northern Greece
}

\author{
Ioannis Tsiripidis • Athanasios Papaioannou • \\ Vasilios Sapounidis • Erwin Bergmeier
}

Received: 23 June 2009 /Accepted: 29 July 2009 /Published online: 18 August 2009

(C) Springer Science + Business Media B.V. 2009

\begin{abstract}
We explore factors responsible for vegetation differentiation in a small-scale serpentine area, and attempt to provide new insights in the complexity of the serpentine factor at community level. We sampled 49 quadrats. From each quadrat physical and chemical soil parameters were measured and species composition, altitude, inclination, aspect and coordinates were recorded. Quadrats were classified and ordination analyses were used to explore the environmental gradients and to estimate the explanatory power of the variables. Generalized linear models were used to investigate the response of species to environmental factors. Variance partitioning was applied to calculate the proportion of variance attributed to different groups of explanatory variables. The gradients revealed were related to soil
\end{abstract}

Responsible Editor: Henk Schat.

I. Tsiripidis $(\bowtie) \cdot V$. Sapounidis

Department of Botany, School of Biology,

Aristotle University of Thessaloniki,

Thessaloniki GR-54124, Greece

e-mail: tsiripid@bio.auth.gr

\section{A. Papaioannou}

School of Forestry and Natural Environment, Aristotle University of Thessaloniki,

Thessaloniki GR-54124, Greece

\section{E. Bergmeier}

Department of Vegetation and Phytodiversity Analysis, Albrecht von Haller Institute of Plant Sciences, University of Göttingen, Untere Karspüle 2, Göttingen 37073, Germany texture, nutrient contents, calcium deficiency, chromium content, climatic parameters and grazing and disturbance intensity. Variance partitioning showed that the highest proportions of variance were attributed to the nutrients and physiographic (including soil texture) variables, while smaller but notable proportions of variance were attributed to geographical coordinates and to metal contents. Our study shows that vegetation differentiation at a local scale is determined by a complex factor of soil properties and climatic parameters, together with variation in disturbance and succession.

Keywords Plant communities $\cdot$ Alyssum chalcidicum - Serpentine vegetation · Heavy metals . Variance partitioning

\section{Introduction}

Ultramafic soils host a specific flora often characterized by local or regional endemic species (Whittaker 1954; Brooks 1987; Chiarucci et al. 2001; Constantinidis et al. 2002; Stevanović et al. 2003; Proctor 2003; Chiarucci and Baker 2007; Grace et al. 2007). Species growing on ultramafic soils have evolved morphological as well as physiological adaptations (Constantinidis et al. 2002; Brady et al. 2005), of which nickel hyperaccumulation is among the most frequently studied (Baker and Brooks 1989; Reeves and Adigüzel 2004). Plant communities found on ultramafic soils are usually significantly distinct from adjacent communities on "normal" soils (Brooks 1987; Robinson et al. 1996). 
The term ultramafic characterises rocks with at least $70 \%$ ferromagnesian, or mafic minerals (Kruckeberg 2002). Soils derived from ultramafic rocks are diverse, but share a number of common characteristics, such as high concentrations of $\mathrm{Mg}, \mathrm{Cr}, \mathrm{Co}$ and $\mathrm{Ni}$ and low concentrations of macronutrients such as $\mathrm{P}, \mathrm{K}, \mathrm{N}$ and Ca (Kruckeberg 1985; Brooks 1987; Robinson et al. 1997; Proctor 2003). Furthermore, ultramafic soils provide physical properties that are unfavourable for plant life, such as shallowness, coarse texture, wide range of diurnal temperature fluctuations and low water holding capacity (Brooks 1987; Huenneke et al. 1990; Robinson et al. 1997; Kruckeberg 2002; Gram et al. 2004; Brady et al. 2005).

Sometimes in literature, the term serpentine is used as a synonym to the term ultramafic. Actually, serpentine soils constitute a subgroup of ultramafic soils which are rich in serpentine minerals. The term has also been used to describe the peculiar characteristics of plant life on ultramafic soils, which are summarized as "serpentine problem", "serpentine factor" or "serpentine syndrome" (Brooks 1987; Brady et al. 2005). Many studies attributed the serpentine problem to the toxic concentrations of metals such as $\mathrm{Ni}, \mathrm{Cr}$ and Co. Nickel is believed to play a major role in determining the flora and vegetation in many serpentine areas (Brooks 1987; Vergnano Gambi 1992; Robinson et al. 1997) because of its relatively high availability in the range of $\mathrm{pH}$ values of serpentine soils and the discovery of a high number of taxa that accumulate $\mathrm{Ni}$ in their tissues (Brooks 1987; Bani et al. 2007). Although relatively high concentrations of $\mathrm{Co}$ are available to plants on ultramafic soils, the phenomenon of its accumulation in plant tissues is rare (Robinson et al. 1997). Chromium, on the other hand, has very low exchangeable concentrations in the soil and no plants are known that hyperaccumulate this element (Brooks 1987; Robinson et al. 1997; Chiarucci 2003). Another possible serpentine factor is the high concentration of $\mathrm{Mg}$ or the deficiency of $\mathrm{Ca}$ or the unfavourable ratio of $\mathrm{Mg}$ to $\mathrm{Ca}$ in serpentine soils. Strong effects of the $\mathrm{Mg} / \mathrm{Ca}$ ratio (Brooks 1987; Proctor and Woodell 1975; Kruckeberg 2002; Roberts and Proctor 1992) and for the toxic influence of $\mathrm{Mg}$ (Proctor 1971; Brooks and Yang 1984; Bani et al. 2007) were found in several studies, and the addition of $\mathrm{Ca}$ to serpentine soils may reverse the unfavorable conditions of these soils to some extent (Proctor 1971; Brooks 1987; Brady et al. 2005).
A third hypothesis concerning the serpentine problem is the low nutrient content of these soils (Brooks 1987; Proctor and Nagy 1992; Chiarucci et al. 1998b). Fertilization with $\mathrm{P}, \mathrm{K}$ or $\mathrm{N}$ enhanced cover and productivity and resulted in a change in the floristic composition of serpentine plant communities (Huenneke et al. 1990; Proctor and Nagy 1992; Chiarucci et al. 1999; Chiarucci and Maccherini 2007; Bani et al. 2007).

While many studies stressed the importance of one or more of the above-mentioned chemical properties, physical properties of serpentine soils should not be neglected. The low water holding capacity of these soils is believed to contribute to the serpentine factor (Huenneke et al. 1990; Angelone et al. 1993; Chiarucci et al. 1998b).

The present study uses an explorative approach to investigate the environmental gradients in a serpentine grassland on Mt Vermio (north-central Greece). Distinct species assemblages of grassland vegetation were observed, differing in structure and cover as well as in floristic composition. The environmental factors considered in this study are those known to influence species distribution and composition on a local scale. The aim of the study is to explore which factors are responsible for vegetation differentiation, and thus to provide new insights in the complexity of the serpentine factor at community level and within a small-scale serpentine area.

\section{Material and methods}

\section{Study area}

The study area is located at the north-eastern slopes of Mt Vermio, in the vicinity of the village Arkochorion (Fig. 1; longitude $22^{\circ} 04^{\prime}$ to $22^{\circ} 08^{\prime} \mathrm{E}$, latitude $40^{\circ}$ $34^{\prime}$ to $40^{\circ} 37^{\prime} \mathrm{N}$ ) and it comprises three subareas. The altitude ranges from 260 to $560 \mathrm{~m}$ a.s.l. The geological substrate is peridotite. Ground inclination in the sampled areas does not exceed $35 \%$. The soils are shallow and the texture is mainly sandy-clayey loam but in some sites sandy loam or clayey loam.

The climate is transitional between mediterranean and submediterranean with annual precipitation around $600 \mathrm{~mm}$, mean annual temperature approximately $15^{\circ} \mathrm{C}$ and a xerothermic period of almost four months (Chochliouros 2005). The vegetation of the wider area, especially where the substrate is not 


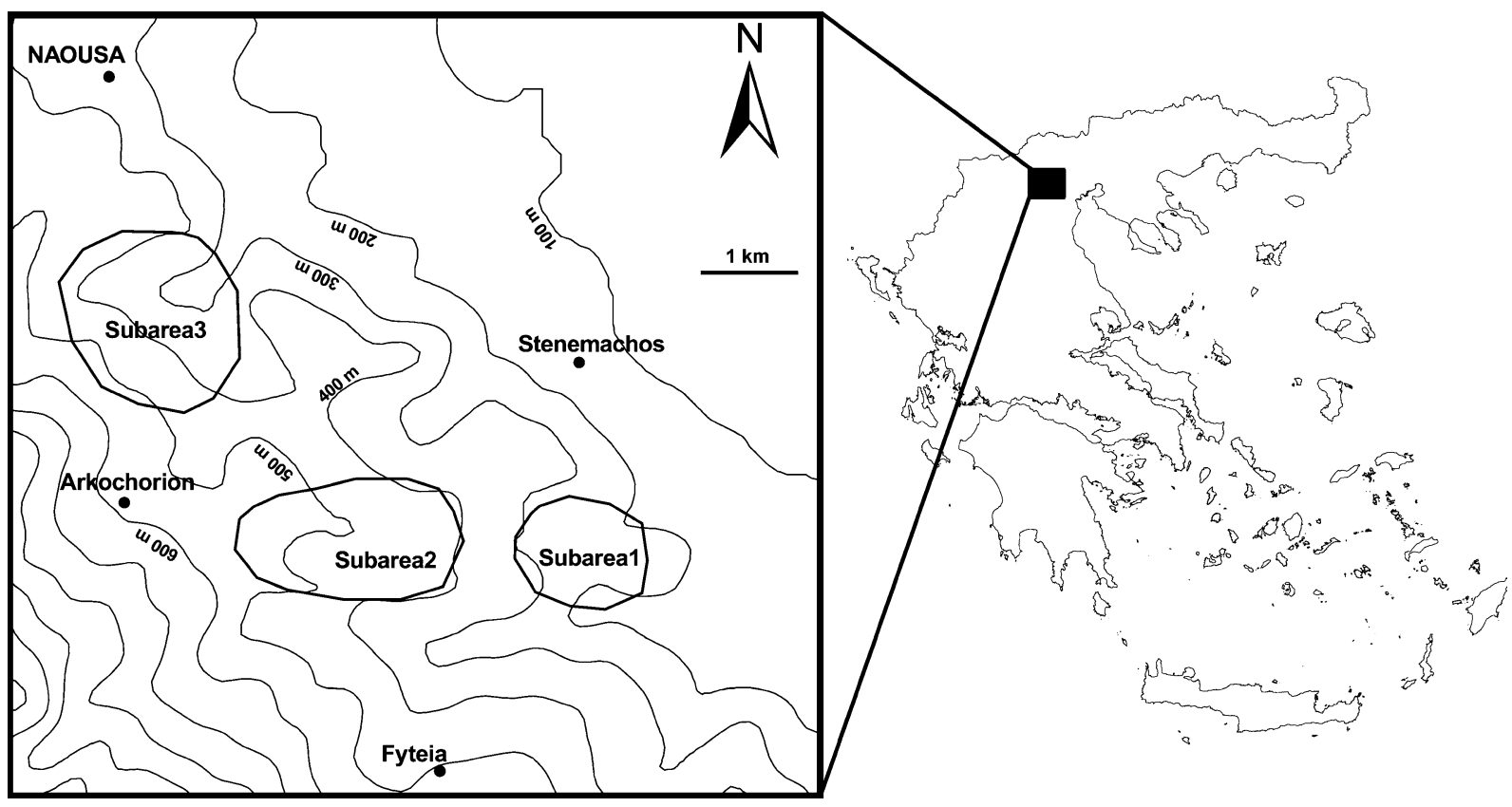

Fig. 1 Map of the study area, showing the three subareas sampled

peridotite, but flysch or schist, is comprised of forests of Quercus frainetto, which at lower altitudes and in drier and/or more disturbed areas are replaced by Quercus pubescens and Carpinus orientalis scrub. All three subareas are grazed but the first two more intensively so.

Vegetation and soil data

In total 49 quadrats (each $1 \mathrm{~m}^{2}$ ) were selected to represent all vegetation types visually recognized in the study area. The sampling was done during the end of spring of 2005. In all selected quadrats at least one individual of Alyssum chalcidicum occurred. This regional serpentinophyte indicates serpentine vegetation (Stevanović et al. 2003, Bergmeier et al. 2009). Species cover and bare soil were measured using the point-quadrat method, with a density of 100 pins $\mathrm{m}^{-2}$ (Moore and Chapman 1986). In each quadrat, altitude, inclination and aspect were measured and the coordinates recorded using a GPS device.

From each quadrat a composite soil sample was taken (merging four subsamples) representing the upper $10 \mathrm{~cm}$ of the topsoil (humus layer and surface litter were excluded). The following soil parameters were measured: acidity (determined electrometrically in a 1:1 soil-water slurry), organic matter (wet oxidation method; Nelson and Sommers 1982) and nitrogen content (Kjeldahl method; Bremmer and Mulvaney 1982), particle size distribution (pipette method; Gee and Bauder 1982), available phosphorus (Olsen method; Olsen and Sommers 1982), exchangeable potassium, magnesium, calcium, sodium (extracted by $1 \mathrm{~N}$ ammonium acetate at $\mathrm{pH}$ 7; Thomas 1982). Exchangeable cations were determined by atomic absorption spectrophotometry. Exchangeable quantities of elements were measured because they represent much better the concentrations available to plants in comparison with total concentrations (Robinson et al. 1996; Chiarucci et al. 1998b). Available zinc, iron, manganese, copper, nickel, cobalt (extracted by DTPA solution; $0.005 \mathrm{M}$ DTPA $+0.01 \mathrm{M} \mathrm{CaCl}_{2}+0.1 \mathrm{M}$ TEA, pH 7.3; Lindsay and Norvell 1978) and chromium (extracted by $\mathrm{HNO}_{3}, 2 \mathrm{M}$; Reisenauer 1982), were also determined by using atomic absorption spectrophotometry (Baker and Amacher 1982). Cobalt concentration was below the limit of detectability and thus was not used in data analysis.

Data analysis

All the soil variables (except $\mathrm{pH}$ and particle size distribution) were expressed in $\mu \mathrm{g} / \mathrm{g}$ and were 
logarithmically transformed by means of the formula $b_{i j}=\log \left(x_{i j}+d\right)-c$, where $b_{i j}$ is the transformed value of $\mathrm{x}_{\mathrm{ij}}, \mathrm{c}$ is order of magnitude constant and is equal to $\operatorname{Int}(\log (\operatorname{Min}(\mathrm{x}))$ (with $\operatorname{Min}(\mathrm{x})$ being the smallest nonzero value in the data and $\operatorname{Int}(\mathrm{x})$ a function that truncates $\mathrm{x}$ to an integer by dropping digits after decimal point), and $\mathrm{d}$ is a decimal constant equal to $\log ^{-1}$ (c) (see McCune and Grace 2002: 69 for further details). Soil acidity $(\mathrm{pH})$ was first transformed to $\mathrm{H}^{+}$ concentration and then subjected to the abovementioned transformation. This treatment of $\mathrm{pH}$ variable should be noted when reading the results of this study, as a positive relation with $\mathrm{H}^{+}$corresponds to a positive relation to more acidic conditions. Inclination, aspect and coordinates from each relevé were used to calculate the potential annual direct incident radiation and heat load by applying the third equation from McCune and Keon (2002). These variables reflect site microclimatic variation.

TWINSPAN (Hill 1979) was applied for the classification of quadrats, using the following percentage abundances as cut levels: $0,1,5,15,30$. Differential species were determined by applying the algorithm proposed by Tsiripidis et al. (2009). Species were considered as differential when the phi coefficient was equal or higher than 0.4. Phi coefficient was calculated for the groups that are positively differentiated vs. the groups found to be differentiated negatively, positivelynegatively or not differentiated at all.

Ordination diagrams of quadrats were made using Detrended Correspondence Analysis (DCA; Hill and Gauch 1980). As (passive) explanatory variables the soil parameters together with altitude, inclination, coordinates (in the form of $\mathrm{X}$ and $\mathrm{Y}$ distances from a zero point), annual direct incident radiation and heat load were used. Kendall's Tau correlation coefficients were calculated between the explanatory variables and the scores of the quadrats on the first two DCA axes as well as the bare soil cover. Kendall's Tau correlation coefficients were also calculated between the explanatory variables.

Canonical Correspondence Analysis (CCA; ter Braak 1986) was applied in order to test which variables have a significant unique contribution to the explanation of species data variance. For this reason a stepwise forward selection of the explanatory variables was applied in CCA and only the variables significant at the 0.05 probability level (using Monte Carlo test with 999 permutations) were considered.
Two CCAs were applied, one with the $\mathrm{X}$ and $\mathrm{Y}$ coordinates included in the explanatory data set and a second with the coordinates excluded.

In order to facilitate the interpretation of the DCA and CCA results, the response of species to the explanatory variables was explored using generalized linear models. Only the differential species occurring at least in 7 quadrats and the non-differential occurring at least in 10 quadrats were considered. For the non-differential species occurring at least in 25 quadrats (these were also the species recorded with the highest cover values) the Poisson distribution with a $\log$ link function was applied. For the other species the Bernoulli distribution (i.e., a binomial distribution where the response variable is converted to binary) with a logit link function was used. In order to simplify interpretation and to avoid overfitting only the models with a linear form were considered, which were significant at the 0.05 probability level.

Mann-Whitney $U$ test with Bonferroni correction for multiple comparisons was applied in order to compare the values of the explanatory variables between the vegetation units and the sampling subareas.

Finally, variance partitioning was applied in order to calculate the proportion of variance explained by different groups of explanatory variables. The algorithm of Økland (2003) for variance partitioning between $\mathrm{n}$ groups of explanatory variables was applied. The explanatory variables were grouped as follows. The first group includes the coordinates, the second the nutrients (organic matter, organic nitrogen, $\mathrm{N}, \mathrm{K}, \mathrm{Ca}, \mathrm{Na}, \mathrm{Cu}, \mathrm{Zn}, \mathrm{Fe}$ and $\mathrm{Mn}$ ), the third the factors that are considered toxic ( $\mathrm{Ni}, \mathrm{Cr}, \mathrm{Mg}, \mathrm{Mg} / \mathrm{Ca}$ ), and the fourth the factors related to physical soil properties and physiography (soil texture, inclination, altitude, annual direct incident radiation and heat load). The first group includes differentiation that cannot be attributed to measured variables, while the latter reflects microclimate and indirectly soil water holding capacity. Soil acidity was not used in any group, as it influences both the availability of nutrients and the solubility of toxic metals. In order to avoid overexplanation of variance, firstly four CCAs were applied, each having one of the four groups as the only explanatory variables. From these CCAs only the variables presenting a significant unique contribution to variance explanation were used in variance partitioning. Following the instructions of Økland (2003) the proportion of variance attributed 
uniquely to each group of variables as well as the shared variance attributed to all the combinations of two, three and four groups were calculated.

TWINSPAN was applied using PC-ORD (ver. 5) (McCune and Mefford 1999) and ordination analyses as well as species response curves were calculated using CANOCO (ver. 4.5) (ter Braak and Šmilauer 2002). Correlation coefficients were calculated with the help of SPSS (ver. 12) (Anon. 2003).

\section{Results}

\section{Classification}

The TWINSPAN classification and the DCA diagrams revealed four species assemblages. Each assemblage is differentiated by unique differential taxa. Additionally, there is a group of differential taxa common to the first and second group, as well as one common to the third and fourth groups. Few other species, differentiating other combinations of assemblages, also exist (Table 1).

The first assemblage appears exclusively in subarea 2 . This subarea is strongly affected by grazing and trampling, particularly so around watering troughs. Although the quadrats are overgrazed they present the second highest vegetation cover (median value of bare soil equal to 23). Subarea 2 is a small plateau with gentle inclination which may be the reason for the relatively high vegetation cover. This assumption is supported by the relatively high percentage of clay in the soils of this group (Table 2). The nitrogen content in this assemblage is the highest, most likely due to the livestock. The higher amount of organic matter of topsoil may be attributed to the higher vegetation cover.

The second assemblage occurs mainly in the subareas 1 and 2, and is represented in subarea 3 by only one quadrat. This assemblage occurs on soils poor in organic matter and its vegetation cover is small (Table 2). Plants are very small $(5-15 \mathrm{~cm})$ and this type of vegetation dries very early, at the beginning of summer.

The third assemblage occurs mainly in subarea 3 and with few quadrats in the other two subareas. This assemblage presents the lowest vegetation cover. The soil is relatively poor in organic matter and nitrogen and other nutrients (e.g. K, $\mathrm{Ca}, \mathrm{Na}, \mathrm{Fe}$ ) and it is of coarse texture (Table 2).
The fourth assemblage has the highest vegetation cover in the study area. It is characterized by the dominance of Chrysopogon gryllus and its structure and composition resembles those of the typical dry grasslands on "normal" soils in the wider area. The soils of this vegetation type are the richest in organic matter and nutrients. Better soil moisture conditions may be assumed due to the finer texture of the soil (higher percentages of silt and clay and smaller of sand) and the lower direct annual radiation and heat load (Table 2).

\section{DCA}

Along the first DCA axis (Fig. 2), the first and second assemblages are separated from the third and fourth. The second axis discriminates the first and fourth assemblages from the second and third.

Most variables present higher and significant correlations with the second DCA axis (Table 3, Fig. 3). Variables significantly correlated with the first axis comprise only the percentage of bare soil, the $\mathrm{Y}$ coordinate and the potassium content. The former variable is more strongly correlated with the second axis, while the other two variables are significantly correlated between each other and reveal the K-poor soils of the third assemblage, spatially confined to subarea 3 . Therefore, the first axis probably reflects differences in soil conditions of the third assemblage, plus possibly other variables not quantified in this study. Based on our observations, we may say that these variables concern grazing intensity, degree of disturbance and the vegetation succession stage. This is also indirectly derived from the fact that the quadrats of the first and fourth assemblages co-occur in subarea 1 and their floristic differentiation indicates a different disturbance intensity as well as succession stage.

The second DCA axis reflects the texture of the soil and the nutrient content. Quadrats with nutrientrich soils and of finer texture appear on the lower part of the second DCA axis. Clay proportion is significantly correlated with most nutrients (Table 4).

CCA and species responses to environmental factors

The variance that each variable explains is presented in Table 5. The Y coordinate and the percentage of clay explain the highest proportions of variance, while the magnesium content and the sand fraction follow. 
Table 1 Synoptic table of the distinguished assemblages $1-4$. The second column (C) gives the absolute constancy of species in the whole data set $(n=49)$, the third column indicates the phi coefficient multiplied by 100 , and fourth to seventh columns specify the relative constancy of species in each assemblage. In the latter columns bold typescript indicates positive differentiation, italic typescript indicates negative differentiation, bold-italic typescript indicates positive-negative differentiation and regular typescript indicates non-differentiation. Phi coefficient was calculated between the assemblages differentiated positively vs. those differentiated negatively, positively-negatively or non-differentiated

\begin{tabular}{|c|c|c|c|c|c|c|}
\hline Assemblage number & $\mathbf{C}$ & Phi & 1 & 2 & 3 & 4 \\
\hline Quadrats per assemblage & & & 7 & 14 & 19 & 9 \\
\hline \multicolumn{7}{|l|}{ Differential species } \\
\hline Veronica arvensis & 6 & 72 & 71 & 0 & 0 & 11 \\
\hline Crepis setosa & 3 & 60 & 43 & 0 & 0 & 0 \\
\hline Galium divaricatum & 17 & 41 & 71 & 29 & 37 & 11 \\
\hline Filago vulgaris & 23 & 86 & 100 & 93 & 11 & 11 \\
\hline Anthemis arvensis ssp. incrassata & 14 & 77 & 100 & 50 & 0 & 0 \\
\hline Vulpia ciliata & 10 & 54 & 71 & 29 & 5 & 0 \\
\hline Sherardia arvensis & 10 & 51 & 57 & 36 & 5 & 0 \\
\hline Plantago lagopus & 8 & 47 & 29 & 43 & 0 & 0 \\
\hline Plantago bellardii & 9 & 56 & 0 & 50 & 11 & 0 \\
\hline Trifolium arvense & 16 & 56 & 14 & 71 & 26 & 0 \\
\hline Daucus broteri & 3 & 41 & 0 & 21 & 0 & 0 \\
\hline Cerastium brachypetalum ssp. roeseri & 6 & 51 & 0 & 0 & 32 & 0 \\
\hline Haplophyllum coronatum & 5 & 46 & 0 & 0 & 26 & 0 \\
\hline Crupina vulgaris & 16 & 41 & 0 & 14 & 58 & 33 \\
\hline Melica ciliata & 4 & 41 & 0 & 0 & 21 & 0 \\
\hline Dorycnium germanicum & 13 & 77 & 0 & 0 & 26 & 89 \\
\hline Thymus longicaulis ssp. chaubardii & 31 & 62 & 14 & 36 & 95 & 78 \\
\hline Hypericum rumeliacum & 22 & 60 & 0 & 14 & 84 & 44 \\
\hline Allium stamineum & 13 & 49 & 0 & 7 & 37 & 56 \\
\hline Asphodeline liburnica & 13 & 47 & 0 & 7 & 42 & 44 \\
\hline Aira elegantissima & 9 & 42 & 0 & 0 & 37 & 22 \\
\hline Prunella laciniata & 16 & 71 & 29 & 14 & 16 & 100 \\
\hline Carex caryophyllea & 15 & 63 & 29 & 7 & 21 & 89 \\
\hline Polygala nicaeensis ssp. mediterranea & 5 & 56 & 0 & 0 & 5 & 44 \\
\hline Danthonia alpina & 3 & 52 & 0 & 0 & 0 & 33 \\
\hline Filipendula vulgaris & 3 & 52 & 0 & 0 & 0 & 33 \\
\hline Centaurium erythraea & 10 & 44 & 14 & 7 & 16 & 56 \\
\hline Poa timoleontis & 21 & 52 & 86 & 50 & 42 & 0 \\
\hline Crepis neglecta ssp. neglecta & 18 & 43 & 43 & 71 & 26 & 0 \\
\hline Linum trigynum & 30 & 48 & 14 & 71 & 68 & 67 \\
\hline Teucrium capitatum & 28 & 42 & 14 & 64 & 68 & 56 \\
\hline Trifolium angustifolium & 13 & 46 & 0 & 57 & 11 & 33 \\
\hline Plantago lanceolata & 17 & 53 & 71 & 7 & 26 & 67 \\
\hline Festuca valesiaca & 15 & 43 & 57 & 0 & 32 & 56 \\
\hline Centaurea spec. & 9 & 44 & 29 & 0 & 37 & 0 \\
\hline \multicolumn{7}{|l|}{ Non-differential species } \\
\hline Alyssum chalcidicum & 49 & & 100 & 100 & 100 & 100 \\
\hline Aegilops triuncialis & 40 & & 57 & 100 & 84 & 67 \\
\hline
\end{tabular}


Table 1 (continued)

\begin{tabular}{|c|c|c|c|c|c|c|}
\hline Assemblage number & $\mathbf{C}$ & Phi & 1 & 2 & 3 & 4 \\
\hline Quadrats per assemblage & & & 7 & 14 & 19 & 9 \\
\hline Chrysopogon gryllus & 36 & & 43 & 50 & 89 & 100 \\
\hline Potentilla detommasii & 36 & & 71 & 79 & 79 & 56 \\
\hline Sanguisorba minor & 33 & & 57 & 50 & 84 & 67 \\
\hline Convolvulus cantabrica & 30 & 37 & 29 & 86 & 68 & 33 \\
\hline Trachynia distachya & 30 & & 71 & 71 & 58 & 44 \\
\hline Dichanthium ischaemum & 27 & & 57 & 79 & 42 & 44 \\
\hline Trifolium campestre & 22 & 28 & 71 & 57 & 37 & 22 \\
\hline Trifolium squamosum & 16 & 39 & 43 & 64 & 11 & 22 \\
\hline Cynosurus elegans & 12 & & 14 & 36 & 16 & 33 \\
\hline Geranium columbinum & 10 & 28 & 29 & 7 & 16 & 44 \\
\hline Anagallis arvensis & 9 & 32 & 43 & 29 & 11 & 0 \\
\hline Medicago minima & 9 & 32 & 43 & 29 & 11 & 0 \\
\hline Arenaria serpyllifolia & 9 & 30 & 43 & 21 & 16 & 0 \\
\hline Silene paradoxa & 8 & 39 & 0 & 0 & 32 & 22 \\
\hline Crepis foetida ssp. rhoeadifolia & 8 & 39 & 0 & 36 & 16 & 0 \\
\hline Cistus creticus & 8 & 36 & 0 & 14 & 32 & 0 \\
\hline Trifolium phleoides & 8 & 33 & 14 & 36 & 11 & 0 \\
\hline Ornithogalum comosum & 8 & 23 & 0 & 21 & 21 & 11 \\
\hline Nigella arvensis ssp. arvensis & 7 & 34 & 0 & 21 & 21 & 0 \\
\hline Hieracium caespitosum & 7 & 21 & 14 & 0 & 21 & 22 \\
\hline Allium guttatum ssp. sardoum & 6 & 20 & 14 & 7 & 21 & 0 \\
\hline Xeranthemum anпuит & 6 & & 14 & 14 & 11 & 11 \\
\hline Anchusa officinalis & 5 & 29 & 0 & 21 & 11 & 0 \\
\hline Leontodon crispus & 5 & 28 & 0 & 0 & 21 & 11 \\
\hline Trifolium cherleri & 5 & 17 & 14 & 21 & 0 & 11 \\
\hline Minuartia recurva ssp. condensata & 5 & & 0 & 14 & 16 & 0 \\
\hline Cynodon dactylon & 4 & 25 & 14 & 21 & 0 & 0 \\
\hline Cerastium pumilum ssp. glutinosum & 4 & & 14 & 7 & 5 & 11 \\
\hline Logfia arvensis & 4 & & 0 & 7 & 16 & 0 \\
\hline Logfia gallica & 4 & & 0 & 14 & 11 & 0 \\
\hline Taeniatherum caput-medusae & 4 & & 0 & 7 & 11 & 11 \\
\hline Bupleurum praealtum & 3 & 35 & 0 & 0 & 5 & 22 \\
\hline Genista carinalis & 3 & 35 & 0 & 0 & 5 & 22 \\
\hline Bellis perennis & 3 & & 14 & 0 & 11 & 0 \\
\hline Cuscuta approximata & 3 & & 0 & 0 & 11 & 11 \\
\hline Dactylis glomerata & 3 & & 0 & 0 & 11 & 11 \\
\hline Dasypyrum villosum & 3 & & 0 & 14 & 0 & 11 \\
\hline Moenchia mantica & 3 & & 0 & 14 & 5 & 0 \\
\hline Ornithogalum umbellatum & 3 & & 14 & 7 & 0 & 11 \\
\hline Petrorhagia illyrica ssp. haynaldiana & 3 & & 0 & 0 & 11 & 11 \\
\hline Salvia viridis & 3 & & 14 & 14 & 0 & 0 \\
\hline Scabiosa tenuis & 3 & & 0 & 14 & 0 & 11 \\
\hline
\end{tabular}




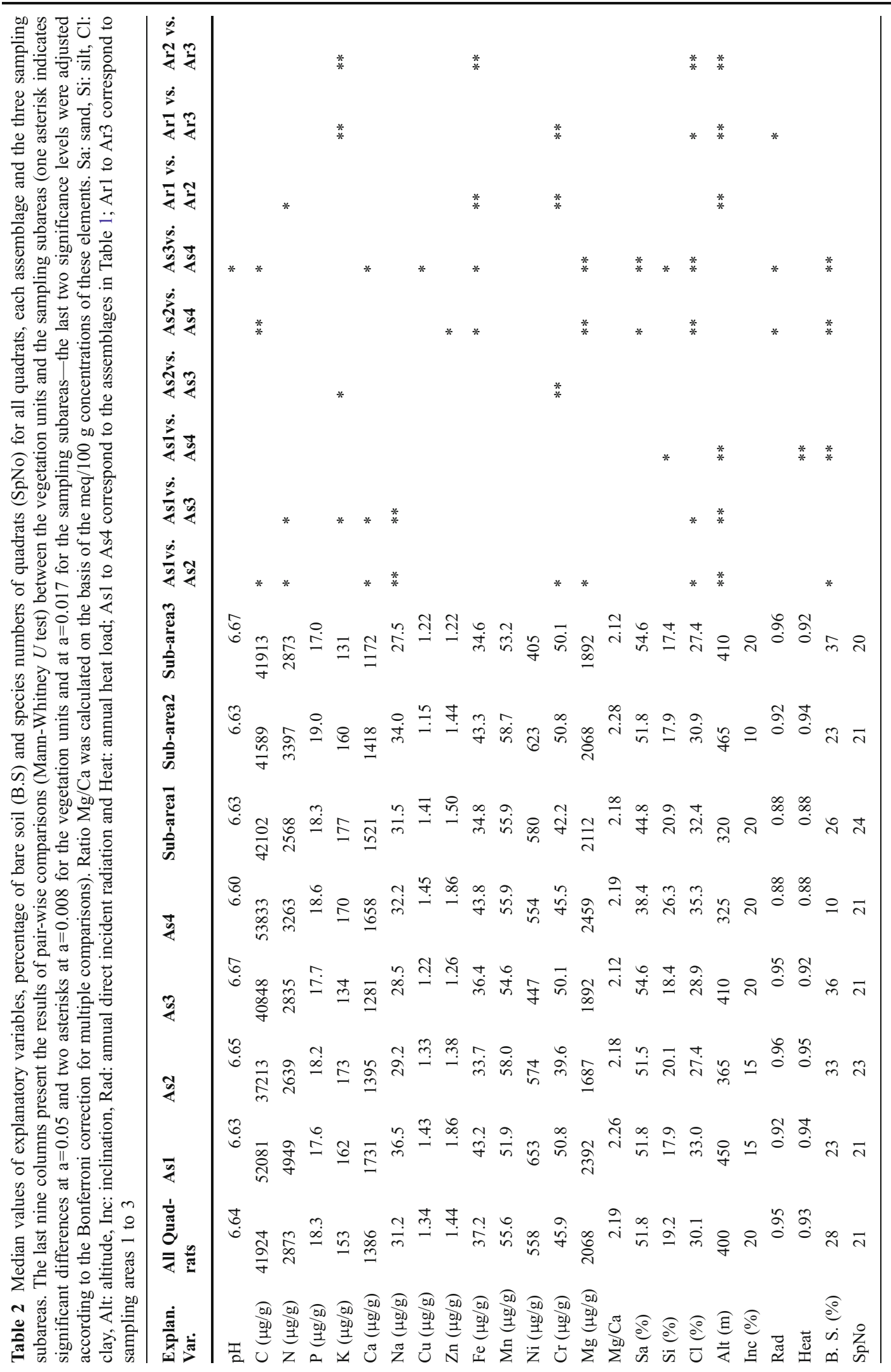




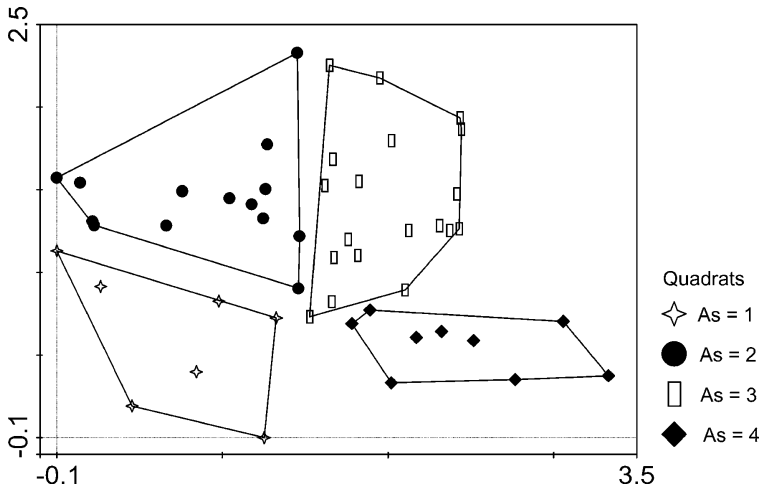

Fig. 2 DCA diagram of quadrats' scores on the first two axes. Eigenvalue and length of 1st axis: 0.401 and 3.331, respectively; corresponding values of 2 nd axis: 0.225 and 2.328 ; total inertia: 2.975

In the forward selection seven variables were found having a significant contribution to the explanation of species data variance. These variables explain $28.2 \%$ of total variance (Table 5). In the CCA where the coordinates were not included in the explanatory variables set, eight variables were found with a significant unique contribution to the explanation of variance. In the latter CCA, $28.9 \%$ of species data variance was explained (Table 5). In this latter CCA the clay percentage and the altitude were chosen as the first two variables. Additionally, in the absence of coordinates, $\mathrm{K}$ and $\mathrm{Cr}$ appear among the significant variables. Conclusively, both CCAs reveal: a) a spatial gradient that accounts for the variance not represented by the measured variables as well as for the differences in $\mathrm{K}$ and $\mathrm{Cr}$ content between the subareas, b) a gradient related to soil texture, c) another related to altitude and thus to climatic parameters, and d) one or more gradients related to nutrients $(\mathrm{K}, \mathrm{Zn}, \mathrm{Na}$ ), the calcium deficiency (or magnesium surplus), and the $\mathrm{Cr}$ content.

The analysis of species response to the measured variables provides a more detailed picture of the species-environment relations (Table 6). No species were found significantly correlated with the variables inclination, Mn and P. Several species are significantly correlated to the coordinates, revealing a spatially structured ecological differentiation. Potassium also explains a significant proportion of variance for a high number of species. Silt, although explaining relatively small proportions of variance, does so for a lot of species. The absolute differential species of the assemblages 1 to 3 are infrequent in the data set and therefore poorly represented in Table 6 . The common differential taxa of assemblages 1 and 2 are mainly correlated to the coordinates and the $\mathrm{K}$ content. The common differential taxa of the assemblages 3 and 4 have a significant proportion of their variance explained by different variables. Moreover, three species (out of six) are significantly related to the $\mathrm{Y}$ coordinate and two species to the $\mathrm{X}$ coordinate, $\mathrm{K}$ and altitude. The absolute differential taxa of the fourth group are significantly correlated to organic matter, soil texture (positively to clay and silt, and negatively to sand percentages), as well as to nutrients such as $\mathrm{Cu}, \mathrm{Fe}, \mathrm{Mg}$ and $\mathrm{Zn}$. From the

Table 3 Variance explained by each variable singly in CCA and Kendall's Tau correlation coefficients between sample scores on the first two DCA axes, percentage of bare soil and explanatory variables; two asterisks indicate significance at $\mathrm{a}=$ 0.01 and one asterisk at $\mathrm{a}=0.05$

\begin{tabular}{|c|c|c|c|c|}
\hline Variables & VE & DCA axis1 & DCA axis2 & Bare Soil \\
\hline DCA axis1 & & & & $-0.21 *$ \\
\hline DCA axis2 & & & & $0.42 * *$ \\
\hline Bare Soil & & $-0.21^{*}$ & $0.42 * *$ & \\
\hline $\mathrm{Cl}$ & 6.39 & & $-0.53 * *$ & $-0.31 * *$ \\
\hline Y & 6.39 & $0.29 * *$ & & \\
\hline $\mathrm{Mg}$ & 5.38 & & $-0.45 * *$ & $-0.21^{*}$ \\
\hline $\mathrm{Sa}$ & 5.38 & & $0.38 * *$ & $0.31 * *$ \\
\hline $\mathrm{X}$ & 4.71 & & & $-0.21^{*}$ \\
\hline $\mathrm{Ca}$ & 4.37 & & $-0.36 * *$ & $-0.26^{* *}$ \\
\hline $\mathrm{Fe}$ & 4.37 & & $-0.44 * *$ & $-0.30 * *$ \\
\hline K & 4.37 & $-0.22^{*}$ & & $-0.26^{* *}$ \\
\hline $\mathrm{C}$ & 4.03 & & $-0.42 * *$ & $-0.32 * *$ \\
\hline $\mathrm{Cu}$ & 4.03 & & $-0.32 * *$ & \\
\hline $\mathrm{Zn}$ & 4.03 & & $-0.30 * *$ & $-0.31 * *$ \\
\hline Alt & 3.7 & & & \\
\hline $\mathrm{H}^{+}$ & 3.7 & & $-0.35 * *$ & $-0.26^{* *}$ \\
\hline $\mathrm{N}$ & 3.7 & & $-0.33 * *$ & \\
\hline $\mathrm{Ni}$ & 3.7 & & $-0.32 * *$ & $-0.36^{* *}$ \\
\hline $\mathrm{Si}$ & 3.7 & & & $-0.22^{*}$ \\
\hline $\mathrm{Mg} / \mathrm{Ca}$ & 3.36 & & & \\
\hline $\mathrm{P}$ & 3.36 & & & \\
\hline $\operatorname{Rad}$ & 3.36 & & $0.28 * *$ & \\
\hline $\mathrm{Na}$ & 3.03 & & $-0.30 * *$ & \\
\hline $\mathrm{Cr}$ & 2.69 & & & \\
\hline Heat & 2.69 & & & \\
\hline Inc & 2.02 & & & \\
\hline $\mathrm{Mn}$ & 1.68 & & & \\
\hline
\end{tabular}




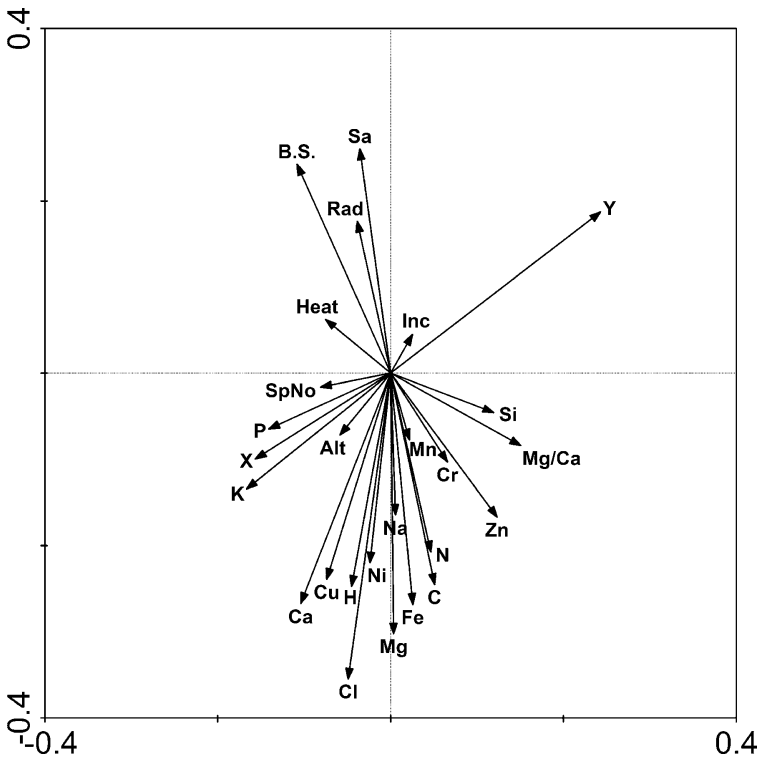

Fig. 3 Environmental variables (arrows) passively projected into the DCA diagram of the first and second DCA axes; for abbreviations of explanatory variables see Tables 2 and 4

remaining differential taxa as well as the common nondifferential species a high proportion (more than 20\%) of their variance is attributed to variables such as altitude (Convolvulus cantabrica), Ca (Dichanthium ischaemum), clay (Plantago lanceolata), K (Aegilops triuncialis, Trifolium squamosum), Mg (Festuca valesiaca), N (Festuca valesiaca), Na (Dichanthium ischaemum), Ni (Geranium columbinum) and geographical coordinates (Potentilla detommasii, Trifolium squamosum, Cynosurus elegans).

Variance partitioning

From each group of explanatory variables at least two variables were found with a significant unique contribution to the explanation of variance. Both $\mathrm{X}$ and $\mathrm{Y}$ coordinates were found significant in the group of spatial variables; $\mathrm{K}, \mathrm{Ca}$ and $\mathrm{Fe}$ were found significant in the group of nutrients; altitude, sand and clay from the group of physiographic variables; and $\mathrm{Mg}$ and $\mathrm{Ni}$ from the group of metals. All these variables explain $33.7 \%$ of the total variance. The results of variance partitioning showed that the highest proportions of variance were attributed to the nutrients and physiographic variables $(7.8$ and $7.6 \%$, respectively), while $6.7 \%$ of the variance is attributable to geographical coordinates and $5.0 \%$ to metals.
The shared variances were small, and those which explained more than $1 \%$ of variance were coordinates and physiography $(1.92 \%)$, and nutrients, physiography and metals $(2.12 \%)$.

\section{Discussion}

Alyssum chalcidicum, a species of the A. murale complex, is a Ni-hyperaccumulator found with high frequency and abundance in serpentine areas of North Greece (Konstantinou 1992; Bergmeier et al. 2009). It is the only obligate serpentinophyte occurring in the four classified assemblages. The relatively strong floristic differentiation of the four assemblages as well as the considerable length of DCA axes reveal high beta diversity in the study area, despite of its small size. Harrison and Inouye (2002) found that serpentine areas in California have a comparatively high diversity of biotic communities, perhaps due to climatic differences among the serpentine "islands". Whittaker (1954; 1960) also found a more rapid turnover in species composition along an altitudinal gradient in serpentine areas compared to nonserpentine areas. Our findings suggest high sensitivity of serpentine vegetation to other factors as well, namely nutrients and disturbances.

The variance explained in both CCAs is relatively small if we take into account the small size of the study area. Chiarucci et al. (2001) found a similarly small proportion of explained variance (around 20\%), which they attributed to stochastic variation of species distribution. In our case, however, part of the unexplained variance is possibly related to grazing or other disturbance intensities as well as different succession stages. The impact of grazing is partly represented by the $\mathrm{Y}$ coordinate as the subareas 1 and 2 (assemblages 1 and 2) are more heavily grazed than subarea 3 (assemblage 3). In the subareas 1 and 2 there are also patches much less disturbed by grazing, where the quadrats of the fourth assemblage were sampled. Grace et al. (2007) found that the second axis of their ordination diagram for the serpentine vegetation of California was not related to climatic or soil variables, but expressed successional history and in particular the histories of fire and livestock grazing. The lack of any correlation of Tuscan garigues with environmental factors was also attributed to the effect 


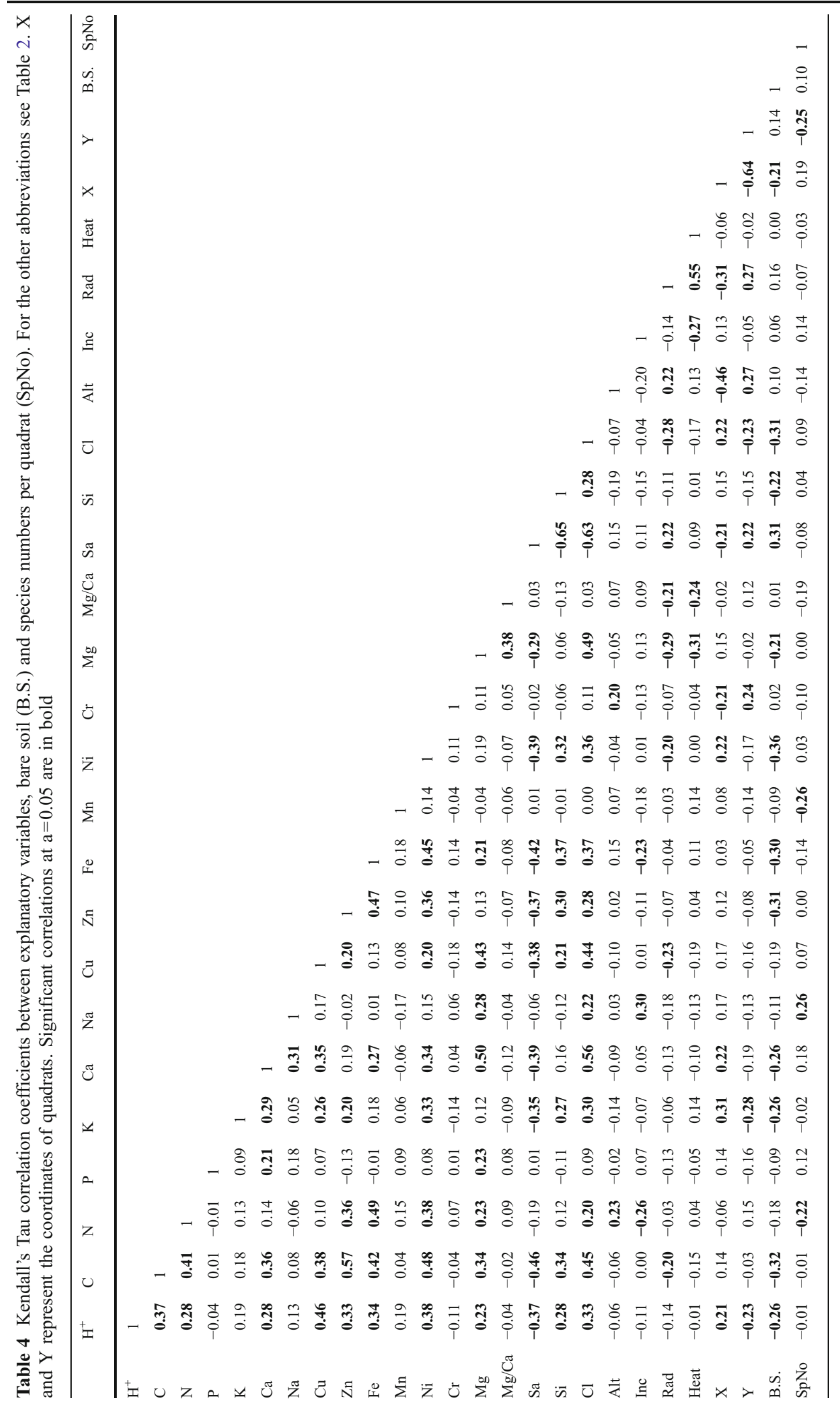


Table 5 Variables that entered the model in the forward selection of CCA. In the first CCA, on the left, $\mathrm{X}$ and $\mathrm{Y}$ coordinates were included in the explanatory data set, while in the second one, on the right, coordinates were excluded from the analysis. AVE: additional proportion of variance that each variable explains at the time of its inclusion in the model, P: significance level of variables, F: F-ratio, TVE: proportion of total variance explained by the significant explanatory variables, Or: inclusion order of variables in the model

\begin{tabular}{|c|c|c|c|c|c|c|c|c|}
\hline Variable & AVE & $\mathbf{P}$ & $\mathbf{F}$ & Or & AVE & $\mathbf{P}$ & $\mathbf{F}$ & Or \\
\hline $\mathrm{Y}$ & 6.39 & 0.001 & 3.22 & 1 & & & & \\
\hline $\mathrm{Cl}$ & 5.38 & 0.001 & 2.73 & 2 & 6.39 & 0.001 & 3.22 & 1 \\
\hline Alt & 4.03 & 0.002 & 2.19 & 3 & 4.03 & 0.005 & 1.98 & 2 \\
\hline $\mathrm{Zn}$ & 3.36 & 0.005 & 1.94 & 4 & 3.70 & 0.006 & 1.9 & 4 \\
\hline $\mathrm{Mg} / \mathrm{Ca}$ & 3.36 & 0.004 & 1.74 & 5 & 3.03 & 0.028 & 1.54 & 5 \\
\hline $\mathrm{Na}$ & 2.69 & 0.024 & 1.58 & 6 & 2.69 & 0.029 & 1.57 & 8 \\
\hline $\mathrm{Sa}$ & 3.03 & 0.013 & 1.61 & 7 & 2.69 & 0.008 & 1.65 & 6 \\
\hline K & & & & & 3.36 & 0.008 & 1.91 & 3 \\
\hline $\mathrm{Cr}$ & & & & & 3.03 & 0.015 & 1.59 & 7 \\
\hline TVE & 28.24 & & & & 28.91 & & & \\
\hline
\end{tabular}

of human disturbance (Chiarucci et al. 1998b; Chiarucci 2003).

The CCA results revealed that among the most important soil variables influencing the floristic composition of the assemblages are those concerning the soil texture. Clay percentage presents also the highest correlation to the second DCA axis. Finer soil texture increases the water holding capacity as well as the cation exchange capacity (clay and silt are positively correlated to most of the measured nutrients; see Table 4). Important factors affecting species composition in serpentine areas are drought (Walker 1954; Proctor and Woodell 1975; Kruckeberg 2002; Chiarucci et al. 1998b; Chiarucci 2003; Gram et al. 2004) and nutrient deficiency (Proctor and Nagy 1992; Chiarucci et al. 2001). Small additional amounts of $\mathrm{N}, \mathrm{P}$ and $\mathrm{K}$ induced vegetation cover and biomass production and in some cases a substantial change in species composition (Huenneke et al. 1990; Proctor and Nagy 1992; Chiarucci et al. 1998a; 1999). The combined effect of drought and nutrient deficiency has been considered an important limiting factor in serpentine soils (Chiarucci 2003). Higher nutrient availability may alleviate the effects of drought (Grime 1990). Chiarucci and Maccherini (2007) observed that the dry Mediterranean climate of Tuscany affects species richness and vegetation cover of serpentine communities only in fertilized plots, while it has non-significant effects in unfertilized ones. Our study corroborates findings that serpentine communities are subject to a combination of climatic and nutritional stress which prevents, or delays, succession.

The soil conditions of the most evolved assemblage (4) in our study area affect in a combined way soil water and nutrients availability. As the soil is moister in this assemblage, plant growth is stimulated. This increases the deposition of dead organic matter and soil organic content, thus improving soil water holding capacity. Furthermore, wetter conditions and humus decay cause soil acidification. Indeed, the $\mathrm{pH}$ in the fourth assemblage is somewhat lower than in the other assemblages. The increase of organic matter content provides a bigger nutrients pool and the decrease of $\mathrm{pH}$ increases nutrients availability (Angelone et al. 1993; Chiarucci 2003).

Another interesting finding of this study is that the concentration of toxic metals is higher in the soils of the more evolved assemblages. For instance, magnesium is significantly higher in assemblages 1 and 4 (see Table 2), and nickel is also higher in these assemblages (see Fig. 3), albeit not significantly. Both these two metals are significantly and positively correlated to the concentration of hydrogen cations (Table 4). This corroborates annotations of Chiarucci (1998b), Chiarucci et al. (2001) and Chiarucci (2003) that the available fraction of metals is higher in the soils under the more developed and structured communities. Note, however, that the available $\mathrm{Cr}$ does not follow the same pattern. 


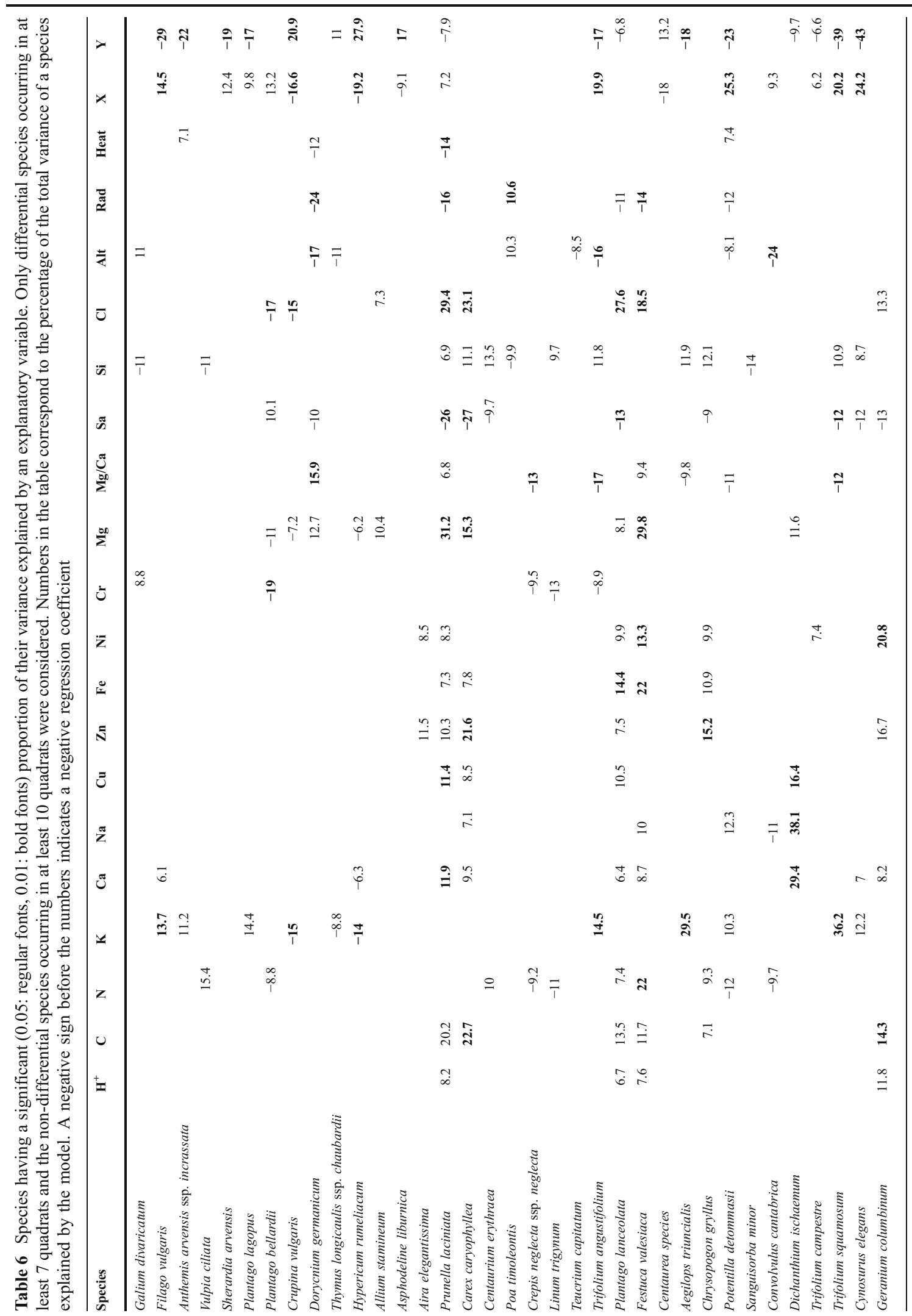


From the variables considered responsible for toxicity effects $(\mathrm{Ni}, \mathrm{Mg}, \mathrm{Cr}, \mathrm{Mg} / \mathrm{Ca}), \mathrm{Mg}$ explains the highest proportion of variance in the CCA. However, as mentioned above this element presents the highest concentration in the more developed assemblages. In the forward selection procedure the variable explaining a significant, unique proportion of variance is the ratio $\mathrm{Mg} / \mathrm{Ca}$. This variable was not found significantly different among the four assemblages and among the three subareas. Additionally, the ratio is relatively small in our study area compared to what is given in other serpentine areas of the world (Brooks 1987; Chiarucci 2003). Chromium, although explaining a small proportion of variance in the CCA, was found to explain a significant unique proportion of variance in the CCA without coordinates. This element is significantly lower in subarea 1 in comparison to the other two subareas. Several authors noticed the limited importance of metal toxicity for the serpentine factor (e.g. Carter et al. 1987; Kruckeberg 1992), and Proctor and Nagy (1992) mentioned that many assumptions about the importance of nickel in determining the serpentine vegetation were unfounded.

A more detailed picture of the dependence of species distribution is obtained by the analysis of species response to the measured variables. Mainly positive correlations with species occurrences were found for both $\mathrm{Mg}$ and $\mathrm{Ni}$, and thus we may not assume toxic effects of these elements. Chromium shows negative correlations with some species, but it explains a low proportion of their variance. Plantago bellardii is an exception. This small annual occurs almost exclusively in subarea 1 where chromium is least concentrated. Also the remaining species correlated negatively with chromium occur mainly in this subarea or are more abundant there.

Another interesting finding is that there is good congruence in the response of species within the differential species groups. Huenneke et al. (1990) observed individualistic responses within species groups (e.g. groups of growth form) to the addition of nutrients. The results of this study, and specifically the fact that the common differential taxa of assemblages 1 and 2 as well as the absolute differential taxa of assemblage 4, showed similar responses to common explanatory variables, indicate that a generalization of certain species responses to environmental factors in serpentine areas may be possible through differential species groups obtained by classification.
The results of variance partitioning provide a direct answer to the question of which factors are main drivers of the vegetation differentiation in the study area. The combined use of explanatory variables and covariables reveals the unique proportion of variance that each group of variables explains (Borcard et al. 1992; Legendre and Legendre 1998; Økland 2003). We conclude that a combination of factors is responsible for the vegetation differentiation at a local scale, notably soil properties and climatic parameters, together with variation in disturbance and succession. Our results show that nutrients and physiographic variables are chiefly responsible for vegetation differentiation, but the other two groups of variables (coordinates and concentration of metals) are also responsible for notable proportions of explained variance. In the group of physiographic variables soil texture plays the major role, while in the group of nutrients, $\mathrm{K}$ and $\mathrm{Ca}$ were found to be relatively more important. Explorative and explanatory studies at different scales are essential to improve our understanding of ecological phenomena in serpentine areas.

Acknowledgements The authors would like to acknowledge Prof. Dimitrios Alifragis for his help and advice during the soil laboratory analyses and two anonymous reviewers for their valuable comments and suggestions.

\section{References}

Angelone M, Vaselli O, Bini C, Coradossi N (1993) Pedogeochemical evolution and trace elements availability to plants in ophiolitic soils. Sci Total Environ 129:291-309

Anon. (2003) SPSS for Windows, Rel. 12.0.0. SPSS Inc., Chicago, IL, US

Baker DE, Amacher MC (1982) Nickel, copper, zinc, and cadmium. In: Page AL et al. (eds) Methods of soil analysis, Part 2: Chemical and microbiological properties. 2nd edn., Madison, pp 323-336

Baker AJM, Brooks RR (1989) Terrestrial higher plants which hyperaccumulate metallic elements - review of their distribution, ecology and phytochemistry. Biorecovery 1:81126

Bani A, Echevarria G, Sulçe S, Morel JL, Mullai A (2007) Insitu phytoextraction of $\mathrm{Ni}$ by a native population of Alyssum murale on an ultramafic site (Albania). Plant Soil 293:79-89

Bergmeier E, Konstantinou M, Tsiripidis I, Sykora K (2009) Plant communities on metalliferous soils in northern Greece. Phytocoenologia (in press)

Borcard D, Legendre P, Drapeau P (1992) Partialling out the spatial component of ecological variation. Ecology 73:1045-1055 
Brady KU, Kruckeberg AR, Bradshaw HD (2005) Evolutionary ecology of plant adaptation to serpentine soils. Annu Rev Ecol Evol Syst 36:243-266

Bremmer JM, Mulvaney CS (1982) Nitrogen-total. In: Page AL et al. (eds) Methods of soil analysis. Part 2: Chemical and microbial properties, 2nd edn., ASA and SSSA, Madison, pp 595-624

Brooks RR (1987) Serpentine and its vegetation: a multidisciplinary approach. Dioscorides Press, Portland, Oregon, USA

Brooks RR, Yang XH (1984) Elemental levels and relationships in the endemic serpentine flora of the Great Dyke, Zimbabwe and their significance as controlling factors for this flora. Taxon 33:392-399

Carter SP, Proctor J, Slingsby DR (1987) Soil and vegetation of the Keen of Hamar serpentine, Shetland. J Ecol 75:21-42

Chiarucci A (2003) Vegetation ecology and conservation on Tuscan ultramafic soils. Bot Rev 69(3):252-268

Chiarucci A, Baker AJM (2007) Advances in the ecology of serpentine soils. Plant Soil 293:1-2

Chiarucci A, Maccherini S (2007) Long-term effects of climate and phosphorus fertilisation on serpentine vegetation. Plant Soil 293:133-144

Chiarucci A, Maccherini S, Bonini I, De Dominicis V (1998a) Effects of nutrient addition on species diversity and cover on "serpentine" vegetation. Plant Biosyst 132:143-150

Chiarucci A, Maccherini S, Bonini I, De Dominicis V (1999) Effects of nutrient addition on community productivity and structure of serpentine vegetation. Plant Biol 1:121126

Chiarucci A, Robinson BH, Bonini I, Petit D, Brooks RR, De Dominicis V (1998b) Vegetation of Tuscan ultramafic soils in relation to edaphic and physical factors. Folia Geobot 33:113-131

Chiarucci A, Rocchini D, Leonzio C, De Dominicis V (2001) A test of vegetation-environment relationships in serpentine soils of Tuscany, Italy. Ecol Res 16:627-639

Chochliouros SP (2005) Floristic and phytosociological research of Mt Vermio-An ecological approach. University of Patra, Greece, Dissertation

Constantinidis T, Bareka EP, Kamari G (2002) Karyotaxonomy of Greek serpentine angiosperms. Bot J Linn Soc 139:109-124

Gee GW, Bauder JW (1982) Particle-size analysis. In: Klute A (ed) Methods of soil analysis, Part 1: Physical and mineralogical methods, 2nd edn. ASA and SSSA, Madison, pp 383-412

Grace JB, Safford HD, Harrison S (2007) Large-scale causes of variation in the serpentine vegetation of California. Plant Soil 293:121-132

Gram WK, Borer ET, Cottingham KL, Seabloom EW, Boucher VL, Goldwasser L, Micheli F, Kendall BE, Burton RS (2004) Distribution of plants in a California serpentine grassland: are rocky hummocks spatial refuges for native species? Plant Ecol 172:159-71

Grime JP (1990) Mechanisms promoting floristic diversity in calcareous grasslands. In: Hillier SH, Walton DWH, Wells DA (eds) Calcareous grasslands: Ecology and management. Bluntisham Books, Bluntisham, England, pp 51-56

Harrison S, Inouye BD (2002) High b diversity in the flora of Californian serpentine 'islands'. Biodivers Conserv 11:1869-1876
Hill MO (1979) TWINSPAN — a FORTRAN program for arranging multivariate data in an ordered two way table by classification of the individuals and the attributes. Cornell University, Ithaca, NY, US, Ecology \& Systematics

Hill MO, Gauch HG (1980) Detrended correspondence analysis: an improved ordination technique. Vegetatio 42:47-58

Huenneke LF, Hamburg SP, Koide R, Mooney HA, Vitousek PM (1990) Effects of soil resources on plant invasion and community structure in Californian serpentine grassland. Ecology 71:478-491

Konstantinou M (1992) Phytosociological studies of the vegetation on metalliferous soils in northern Greece. Aristotle University of Thessaloniki, Greece, Dissertation

Kruckeberg AR (1985) California serpentines: flora, vegetation, geology, soils, and management problems. Univ. Calif. Press, Berkeley

Kruckeberg AR (1992) Plant life of western North American ultramafics. In: Roberts BA, Proctor J (eds) The ecology of areas with serpentinized rocks: A world view. Kluwer Academic Publishers, The Netherlands, pp 31-74

Kruckeberg AR (2002) Geology and plant life: the effects of land forms and rock types on plants. University of Washington Press, Seattle, USA

Legendre P, Legendre L (1998) Numerical ecology, 2nd, Englishth edn. Elsevier Science, Amsterdam, NL

Lindsay WL, Norvell WA (1978) Development of a DTPA soil test for zinc, iron, manganese, and copper. Soil Sci Soc Am J 42:421-428

McCune B, Grace JB (2002) Analysis of ecological communities. MJM Press, Gleneden Beach, Oregon, USA

McCune B, Keon D (2002) Equations for potential annual direct incident radiation and heat load. J Veg Sci 13:603606

McCune B, Mefford MJ (1999) PC-ORD - Multivariate analysis of ecological data. Version 5.0. MjM Software, Gleneden Beach, Oregon, USA

Moore PD, Chapman SB (1986) Methods in plant ecology. Blackwell Scientific Publications, Oxford

Nelson DW, Sommers LE (1982) Total carbon, organic carbon and organic matter. In: Page AL et al. (eds) Methods of soil analysis. Part 2: Chemical and microbial properties, 2nd edn., ASA and SSSA, Madison, pp 39-579

Økland RH (2003) Partitioning the variation in a plot-byspecies data matrix that is related to $\mathrm{n}$ sets of explanatory variables. J Veg Sci 14(5):693-700

Olsen SR, Sommers LE (1982) Phosphorus. In: Page AL et al. (eds) Methods of soil analysis. Part 2: Chemical and microbial properties, 2nd edn., ASA and SSSA, Madison, pp 401-430

Proctor J (1971) The plant ecology of serpentine. III. The influence of a high magnesium/calcium ratio and high nickel and chromium levels in some British and Swedish serpentine soils. J Ecol 59:827-842

Proctor J (2003) Vegetation and soil and plant chemistry on ultramafic rocks in the tropical Far East. Perspect Plant Ecol 6:105-124

Proctor J, Nagy L (1992) Ultramafic rocks and their vegetation: an overview. In: Baker AJM, Proctor J, Reeves RD (eds) The vegetation of ultramafic (serpentine) soils. Kluwer Academic Publishers, Dordrecht, pp 469-494 
Proctor J, Woodell SRJ (1975) The ecology of serpentine soils. Adv Ecol Res 9:255-366

Reeves RD, Adigüzel N (2004) Rare plants and nickel accumulators from Turkish serpentine soils, with special reference to Centaurea species. Turk J Bot 28:147-153

Reisenauer HM (1982) Chromium. In: Page AL et al. (eds) Methods of soil analysis. Part 2: Chemical and microbiological properties. 2nd edn., Madison, pp 323-336

Roberts BA, Proctor J (1992) The ecology of areas with serpentinized rocks: a world view. Kluwer, Dordrecht, Netherlands

Robinson BH, Brooks RR, Kirkman JH, Gregg PEH, Alvarez HV (1997) Edaphic influences on a New Zealand ultramafic ("serpentine") flora: a statistical approach. Plant Soil 188:11-20

Robinson BH, Brooks RR, Kirkman JH, Gregg PEH, Gremigni P (1996) Plant-available elements in soils and their influence on the vegetation over ultramafic ('Serpentine') rocks in New Zealand. J R Soc New Zeal 26:457-458

Stevanović V, Tan K, Iatrou G (2003) Distribution of the endemic Balkan flora on serpentine I.- obligate serpentine endemics. Plant Syst Evol 242:149-170 ter Braak CJF (1986) Canonical correspondence analysis: a new eigenvector technique for multivariate direct gradient analysis. Ecology 67:1167-1179

ter Braak CJF, Šmilauer P (2002) CANOCO reference manual and CanoDraw for Windows user's guide: Software for canonical community ordination (version 4.5). Microcomputer Power, Ithaca, NY, US

Thomas GW (1982) Exchangable cations. In: Page AL et al. (eds) Methods of soil analysis. Part 2: Chemical and microbial properties, 2nd edn., ASA and SSSA, Madison, pp 154-157

Tsiripidis I, Bergmeier E, Fotiadis G, Dimopoulos P (2009) A new algorithm for the determination of differential taxa. $\mathrm{J}$ Veg Sci 20:233-240

Vergnano Gambi O (1992) The distribution and ecology of the vegetation of ultramafic soils of Italy. In: Roberts BA, Proctor J (eds) The Ecology of Areas with Serpentinized Rocks: A World View. Kluver, Dordrecht, NL, pp 217-247

Walker RB (1954) The ecology of serpentine soils: A symposium. II. Factors affecting plant growth on serpentine soils. Ecology 35:259-66

Whittaker RH (1954) The vegetational responses to serpentine soils. Ecology 35:275-288

Whittaker RH (1960) Vegetation of the Siskiyou Mountains, Oregon and California. Ecol Monogr 30:279-338 